\title{
PERBEDAAN PENAMBAHAN DOSIS PROBIOTIK PADA PAKAN TERHADAP TINGKAT KELANGSUNGAN HIDUP DAN PERTUMBUHAN BENIH IKAN PATIN (Pengasius hypophthalmus)
}

\author{
Oleh: \\ Sri Sukari Agustina ${ }^{(1)}$, Aonuraofiq ${ }^{(2)}$, dan Rudi Nursin ${ }^{(3)}$ \\ ${ }^{(1),(2)}$ Staf Pengajar Fakultas Perikanan UNISMUH Luwuk Kabupaten Banggai \\ ${ }^{(3)}$ Alumni Fakultas Perikanan Universitas Muhammadiyah Luwuk
}

\begin{abstract}
Abstrak
Tujuan penelitian ini adalah untuk menganalisis perbedaaan penambahan dosis probiotik pada pakan buatan terhadap tingkat kelangsungan hidup dan pertumbuhan benih ikan patin (Pengasius hypophthalmus). Penelitian ini menggunakan wadah styrofoam dengan ukuran 48 x 38 x $18 \mathrm{~cm}^{2}$. Hewan uji yang digunakan adalah benih ikan patin (Pengasius hypophthalmus) dengan ukuran berat 14-21 gram serta padat tebar 3 ekor/wadah. Rancangan yang digunakan adalah Rancangan Acak Lengkap (RAL) dengan 3 perlakuan dan 3 kali ulangan, dimana perlakuan A menggunakan penambahan dosis probiotik $1 \%$ pada pakan, perlakuan B menggunakan penambahan dosis probiotik 3\% dan perlakuan $\mathrm{C}$ menggunakan penambahan dosis probiotik 5\%. Untuk mengetahui pebedaan di antara perlakuan maka dilakukan uji Beda Nyata Terkecil (BNT). Pengukuran peubah yang digunakan yaitu tingkat kelangsungan hidup (SR) dan pertumbuhan mutlak. Hasil analisis penelitian, diperoleh bahwa perbedaan penambahan dosis probiotik dalam pakan tidak memberikan perbedaan yang nyata pada tingkat kelangsungan hidup benih ikan patin (Pengasius hypophthalmus), tetapi memberikan perbedaan yang nyata pada pertumbuhan mutlak. Dari ketiga perlakuan perbedaan penambahan dosis probiotik yang diberikan diperoleh pertumbuhan mutlak untuk perlakuan $\mathrm{C}$ (5\%) sebesar 8,40 $\pm 0,70$ gram, pada perlakuan B (3\%) sebesar 6,17 $\pm 0,23$ gram dan diikuti pelakuan A (1\%) sebesar 5,80 \pm 1,51 gram. Hasil pengukuran kualitas air yang meliputi suhu dan $\mathrm{pH}$ selama penelitian menunjukkan angka yang masih layak untuk kehidupan benih patin dengan kisaran suhu $25-26^{\circ} \mathrm{C}$ dan $\mathrm{pH} 7,5-8$.
\end{abstract}

Kata kunci : pakan, probiotik, ikan patin

\section{PENDAHULUAN}

Pengembangan budidaya air tawar di Indonesia merupakan salah satu prioritas yang diharapkan menjadi sumber pertumbuhan dari sektor perikanan, apalagi ditunjang dengan sumber daya alam yang tersedia sehingga mampu mendorong pembangunan sektor perikanan. Ikan patin (Pengasius hypophthalmus) merupakan salah satu komoditas unggulan ikan air tawar yang mudah dibudidayakan serta mempunyai nilai eknomis yang tinggi. Patin adalah salah satu jenis ikan dari kelompok lele-lelean (catfish) yang menjadi salah satu komoditas unggulan ikan air tawar. Hal ini karena ikan patin memiliki pangsa pasar cukup besar, baik didalam negeri maupun luar negeri dengan nilai jual cukup tinggi (Mahyuddin, 2010).

Ikan patin memiliki beberapa sifat menguntungkan untuk dibudidayakan seperti ukuran per individu yang besar, kemampuan bertelur yang cukup tinggi, kebiasaan makan yang omnivora, serta mutu dagingnya yang digemari masyarakat luas Arifin (1987) dalam Atemalem (2001). Ikan patin sebagai komoditas perikanan dengan nilai ekonomis tinggi belum banyak yang dibudidayakan secara benar sehingga banyak sekali 
hal yang harus diteliti dalam kaitannya dengan teknik budidaya agar kegiatan budidaya yang dilakukan dapat berhasil.

Banyak pengalaman petani budi daya ikan harus melakukan panen secara bertahap karena ukuran ikan saat ditebar sama tetapi mengalami pertumbuhan yang berbeda-beda. Beberapa rekayasa dan upaya dilakukan untuk mempercepat pertumbuhan ikan patin agar ukurannya seragam, sehingga efisiensi produksi budi daya ikan patin menjadi cukup baik. Para pembudidaya ikan menempuh cara dengan memberikan makanan berprotein tinggi dan memberikan makanan alami seperti keong, bekicot dan lain-lain. Pada beberapa budi daya ikan seperti budi daya ikan nila, ikan patin dan ikan-ikan lainnya, pemberian probiotik telah dirasakan manfatnya dalam mempercepat pertumbuhan ikan.

Probiotik merupakan mikroorganisme hidup yang sangat bermanfaat bagi makhluk hidup. Mikroorganisme yang terkandung pada probiotik mampu membantu pencernakan makanan pada tubuh hewan dan manusia sehingga makanan yang mengandung probiotik akan mampu dicerna dan diserap tubuh dengan baik. Mikroorgaisme di dalam saluran pencernaan mempunyai peran penting dalam meningkatkan daya cerna sehingga mempercepat proses pencernaan dan pertumbuhan ikan. Selain itu probiotik mampu meningkatkan kekebalan tubuh dari serangan penyakit. Adanya penambahan probiotik pada pakan buatan dapat meningkatkan kandungan nitrisi protein pakan serta menjaga keseimbangan mikroba saluran pencernaan (Kusriningrum. et.al, 2008).

Irianto (2007) dalam Supriyanto (2010) menyatakan bahwa pada budi daya ikan probiotik diberikan sebagai campuran makanan dan ada yang ditaburkan pada kolam pemeliharaan. Untuk Probiotik yang dicampur pakan, bisa dicampurkan dengan pakan buatan pabrik (pakan) maupun pakan alami seperti daun-daunan. Probiotik itu sendiri adalah makanan tambahan (suplemen) berupa sel-sel mikroorganisme hidup yang memiliki pengaruh menguntungkan bagi hewan inang yang mengkonsumsinya melalui penyeimbangan flora mikroorganisme intestinal dalam saluran pencernaan. Pemberian organisme probiotik dalam akuakultur dapat diberikan melalui pakan, air maupun melalui perantaraan pakan hidup seperti rotifera atau artemia. Penggunaan probiotik dalam ransum ternyata dapat meningkatkan daya cerna sehingga zat-zat pakan lebih banyak diserap oleh tubuh untuk pertumbuhan maupun produksi Barrow (1992) dalam Laksmiwati (2009).

Tujuan penelitian ini adalah untuk menganalisis perbedaan dosis probiotik pada pakan sehingga dapat memberikan tingkat kelangsungan hidup dan pertumbuhan yang optimal pada benih ikan patin.

\section{METODE PENELITIAN}

Penelitian ini dilaksanakan mulai bulan Juni sampai dengan bulan Juli 2012 di Laboratorium Stasiun Karantina Ikan Bubung Kecamatan Luwuk Kabupaten Banggai Provinsi Sulawesi Tengah. Hewan uji yang digunakan yaitu benih ikan patin yang berukuran 14-21 gr. Rancangan yang digunakan dalam penelitian ini yaitu Rancangan 
Acak Lengkap (RAL) dengan 3 perlakuan penggunaan dosis probiotik super NB yaitu perlakuan A (penambahan dosis probiotik 1\% pada pakan), perlakuan B (penambahan dosis probiotik 3\% pada pakan) dan perlakuan $\mathrm{C}$ (penambahan dosis probiotik $5 \%$ pada pakan) dan masing-masing perlakuan terdiri dari 3 ulangan.

Prosedur penelitian yaitu mempersiapan wadah percobaan berupa styrofoam yang berukuran $48 \times 38 \times 18 \mathrm{~cm}^{2}$ dan perlengkapan (aerator, batu aerasi, selang aerasi) sesuai dengan denah pecobaan, pakan dan probiotik untuk hewan uji, mengisi air ke dalam wadah percobaan sekitar 5 liter dan mengadaptasikan hewan uji kedalam wadah selama dua hari. Setelah tahap persiapan selesai dilanjutkan dengan menimbang hewan uji sebelum dimasukan ke dalam wadah percobaan untuk penentuan bobot biomassa, memasukan hewan uji kedalam wadah percobaan sesuai perlakuan dengan kepadatan 3 ekor per wadah, menambahkan probiotik pada pakan serta memberikan pada hewan uji dengan dengan dosis $5 \%$ dari berat biomassa dan frekuensi pemberian 2(dua) kali sehari yaitu pada pukul 09:00 dan 16:00, melakukan penyiponan kotoran dalam wadah percobaan pada saat penggantian air sebanyak $3 \%$ pada pagi hari, melakukan pengamatan terhadap tingkat kelangsungan hidup hewan uji setiap hari serta melakukan penimbangan hewan uji setiap II (dua ) minggu sekali serta melakukan pengamatan dan pengukuran kualitas air berupa $\mathrm{pH}$ dan suhu, 3 (tiga) kali selama penelitian, pengukuran dilakukan pada pagi, siang dan sore hari.

Parameter yang diamati selama penelitian yaitu tingkat kelangsungan hidup dan pertumbuhan benih ikan patin. Untuk menghitung tingkat kelangsungan hidup benih ikan patin digunakan rumus Castel dan Tiews (1980) dalam Saputra et al. (2010) :

$\boldsymbol{S} \boldsymbol{R}(\%)=\frac{\mathrm{Nt}}{\mathrm{No}_{\mathrm{o}}} \times 100 \%$

Keterangan :

SR : Survival Rate (\%)

$\mathrm{Nt}$ : Jumlah ikan akhir (ekor)

$\mathrm{N}_{\mathrm{o}}$ : Jumlah ikan awal (ekor)

Sedangkan untuk mendapatkan data pertumbuhan mutlak digunakan rumus untuk (Effendie, 1979) :

$$
\begin{aligned}
& \mathrm{W}=\mathrm{Wt}-\mathrm{W}_{\mathrm{o}} \\
& \text { Keterangan }: \\
& \mathrm{W}=\text { Pertumbuhan mutlak }(\mathrm{gr}) \\
& \mathrm{Wt}=\text { Berat rata-rata akhir }(\mathrm{gr}) \\
& \mathrm{W}_{\mathrm{o}}=\text { Berat rata-rata awal }(\mathrm{gr})
\end{aligned}
$$

Untuk mengetahui pengaruh pemberian pakan yang dicampurkan probiotik terhadap tingkat kelangsungan hidup dan pertumbuhan mutlak benih ikan patin, maka data yang diperoleh selama penelitian dianalisis dengan menggunakan analisis sidik ragam. Apabila perlakuan memberikan pengaruh nyata maka dilanjutkan dengan Uji Beda Nyata Terkecil (Gaspers, 1995). 


\section{HASIL DAN PEMBAHASAN \\ Tingkat Kelangsungan Hidup (Survival Rate)}

Hasil analisis penelitian perbedaan penambahan dosis probiotik pada pakan terhadap tingkat kelangsungan hidup benih ikan patin (Pengasius hypophthalmus) selama penelitian didapatkan data rata-rata tingkat kelangsungan hidup benih ikan patin yang tersaji pada Tabel 1 .

Tabel 1. Rata-rata tingkat kelangsungan hidup benih ikan patin dengan perbedaan penambahan dosis probiotik pada pakan

\begin{tabular}{c|c}
\hline Perlakuan & Tingkat Kelangsungan Hidup (\%) \\
\hline & $\mathrm{X} \pm \mathrm{SD}$ \\
\hline A (Probiotik 1\%) & $88,89 \pm 19,23^{\mathrm{a}}$ \\
B (Probiotik 3\%) & $100,00 \pm 0,00^{\mathrm{a}}$ \\
C (Probiotik 5\%) & $88,89 \pm 19,24^{\mathrm{a}}$ \\
\hline
\end{tabular}

Keterangan : ${ }^{a}$ Huruf yang sama pada kolom yang sama menyatakan tidak berbeda nyata pada $\operatorname{taraf} \alpha<5 \%$.

Hasil analisis Tabel 1 menunjukkan bahwa perbedaan penambahan dosis probiotik pada pakan tidak memberikan perbedaan yang tidak nyata terhadap tingkat kelangsungan hidup benih ikan patin pada masing-masing perlakuan. Artinya perlakuan A tidak berbeda nyata dengan perlakuan $\mathrm{B}$ dan perlakuan $\mathrm{C}$, hal ini karena probiotik dapat memperbaiki pakan atau dapat memperbaiki nutrisinya sehingga mudah dicerna dalam saluran pencernaan pada ikan patin (Pengasius hypophthalmus) serta membantu daya tahan ikan. Walker dan Clymo (1996) dalam Atira, (2009) menyatakan bahwa bakteri positif dapat meningkatkan laju pertumbuhan dan mengurangi tingkat mortalitas organisme akuakultur, diantaranya pada ikan. Fuller (1989) dalam Atira (2009) melaporkan bahwa probitik menguntungkan hewan dengan meningkatkan keseimbangan mikroorganisme di dalam usus.

Rata-rata tingkat kelangsungan hidup benih ikan patin pada perlakuan A sebesar $88,89 \%$ sama dengan perlakuan $\mathrm{C}$, hal ini bahwa kandungan bakteri yang ada pada perlakuan A dengan kandungan dosis probiotik $1 \%$ yang mengalami kematian pada hari ke 26 diduga populasi bakteri yang ada pada saluran pencernaan sedikit sehingga bakteri pathogen masih dapat bersaing, sementara pada perlakuan $\mathrm{C}$ kematian benih ikan pada hari ke 28 yang diduga populasi bakteri ini telah terjadi persaingan sesama jenis dalam aktivitas pengambilan nutrisi sehingga kerja bakteri terhambat. Richard (1993) dalam Gandara (2004) menduga bahwa akibat terlalu tingginya populasi bakteri sehingga menimbulkan persaingan sesama jenis bakteri dalam pengambilan nutrisi atau substrat yang pada akhirnya aktifitas bakteri di dalam saluran pencernaan terhambat dan sekresi enzim pun menurun. Bret dan Groves (1979) dalam Puput (2010) menyatakan bahwa probiotik yang dicampurkan dalam pakan memiliki pengaruh bagi hewan inang yang mengkonsumsinya.

Rata-rata tingkat kelangsungan hidup benih ikan patin paling tinggi pada perlakuan B sebesar $100 \%$, ini dikarenakan tingkat populasi bakteri probiotik serta 
dosisnya dapat mempertahankan tingkat kelangsungan hidup benih ikan patin. Dengan pemberian probiotik akan menjadikan benih tahan terhadap penyakit.

Menurut Irianto (2004) dalam Malik (2008) untuk meningkatkan kualitas pakan adalah pemanfaatan mikroba. Pemanfaatan mikroba tersebut dilakukan melalui penambahan mikroba secara langsung ke dalam pakan, karena mikroba tersebut berperan dalam perbaikan pakan melalui proses fermentasi dengan menguraikan materi pakan yang sulit dicerna hewan budidaya dan meningkatkan kandungan protein. Bacillus sp. adalah bakteri positif yang bersifat fakultatif, memiliki kemampuan menghidrolisis polisakarida, protein, lemak, dan asam nukleat serta mengubahnya menjadi produk hidrolisis Fardiaz (1992) dalam Aslamyah (2009).

\section{Pertumbuhan Mutlak}

Hasil analisis penelitian perbedaan penambahan dosis probiotik pada pakan terhadap pertumbuhan mutlak benih ikan patin (Pengasius hypophthalmus) selama penelitian didapatkan data rata-rata pertumbuhan mutlak benih ikan patin yang tersaji pada Tabel 2.

Tabel 2. Rata-rata pertumbuhan mutlak benih ikan patin dengan perbedaan penambahan dosis probiotik pada pakan

\begin{tabular}{c|c}
\hline Perlakuan & Pertumbuhan Mutlak (gram) \\
\hline A (Probiotik 1\%) & SD \\
B (Probiotik 3\%) & $5,80 \pm 1,51^{\mathrm{a}}$ \\
C (Probiotik 5\%) & $6,17 \pm 0,23^{\mathrm{a}}$ \\
\hline
\end{tabular}

Keterangan : ${ }^{a}$ : huruf pada kolom yang sama menunjukan tidak berbeda nyata pada $(\alpha<0,05)$ ${ }^{\text {ab }}$ : huruf pada kolom yang sama menunjukan berbeda nyata pada $(\alpha>0,05)$

Hasil analisis Tabel 2, didapatkan bahwa pemberian probiotik dengan dosis yang berbeda memberikan perbedaan yang nyata terhadap pertumbuhan mutlak pada masingmasing perlakuan, dimana perlakuan $\mathrm{C}$ (probiotik 5\%) berbeda nyata dengan perlakuan A dan perlakuan B sedangkan perlakuan A tidak berbeda nyata dengan perlakuan B. Hal ini diduga bakteri yang masuk ke dalam saluran pencernaan meningkat seiring dengan pemberian probiotik pada pakan sehingga mampu untuk meningkatkan pertumbuhan pada benih ikan patin. Peningkatan daya cerna bermakna pula pada semakin tinggi nutrisi yang tersedia untuk di serap tubuh, sehingga pertumbuhan meningkat. Bakteri di dalam saluran pencernaan ikan mensekresikan enzim-enzim pencernaan seperti protease dan amilase (Ferdiaz, 1992 dalam Gandara, 2004). Enzim yang disekresikan ini jumlahnya meningkat sesuai dengan jumlah dosis probiotik yang diberikan, sehingga jumlah pakan yang di cerna juga meningkat (Gandara, 2004).

Perlakuan $\mathrm{C}$ (probiotik $5 \%$ ) memberikan rata-rata pertumbuhan mutlak benih ikan patin tertinggi, sedangkan perlakuan A (probiotik 1\%) memberikan rata-rata pertumbuhan mutlak terendah, pada perlakuan C populasi bakteri probiotik yang ada dalam saluran pencernaan meningkat sesuai dengan kebutuhan pertumbuhan benih ikan patin. Penambahan bakteri probiotik pada pakan akan mempengaruhi kinerja atau aktifitas enzim pencernaan, sehingga proses pencernaan dan penyerapan nutrient pakan 
oleh tubuh ikan lebih baik. Jumlah bakteri yang masuk ke dalam saluran pencernaan ikan dan hidup di dalamnya meningkat sejalan dengan dosis probiotik yang di berikan (Gandra, 2004). Efeendie (1997) dalam Maesaroh (2004) menyatakan bahwa energi yang diperoleh dari pakan yang dikonsumsi pertama akan digunakan untuk memelihara tubuh, pergerakan dan mengganti sel-sel yang rusak, selebihnya digunakan untuk pertumbuhan. Pertumbuhan mutlak ikan patin pada setiap perlakuan selama penelitian tersaji pada Gambar berikut :

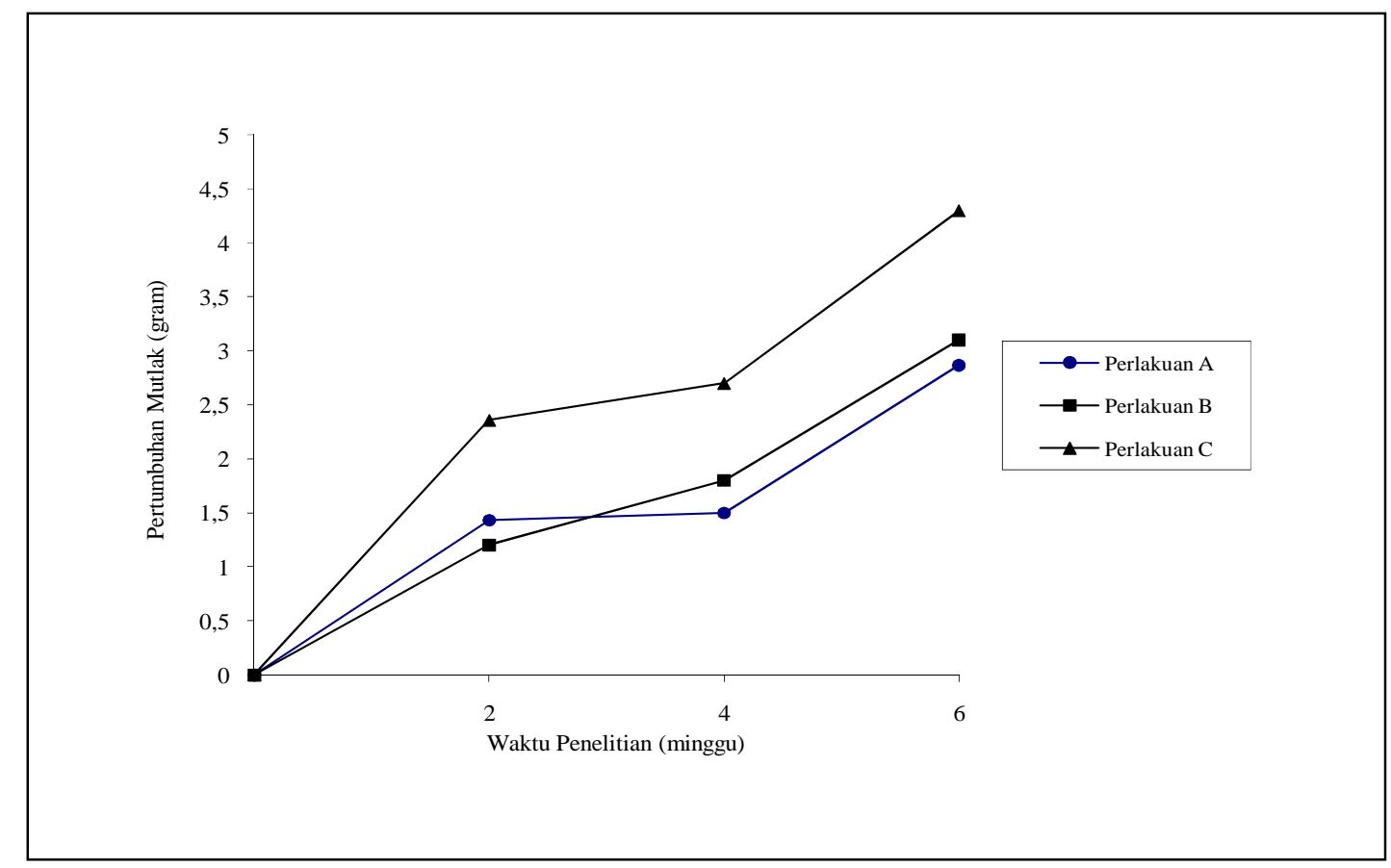

Gambar : Pertumbuhan mutlak (gram) ikan patin pada setiap perlakuan selama penelitian

Pada Gambar terlihat bahwa pada awal penelitian sampai minggu ke dua terjadi kenaikan pertumbuhan mutlak pada masing-masing perlakuan sampai pada minggu ke enam ini dipengaruh adanya probiotik yang diberikan langsung ke pakan, mikroba yang ada dalam saluran pencernaan benih ikan patin dapat berfungsi untuk mencernakan pakan. Pertumbuhan menjadi lambat masuk pada minggu keempat ini diduga bahwa kepadatan serta waktu pemberian probiotik yang mempengaruhi pertumbuhan benih ikan patin tersebut. Kepadatan dan waktu pemberian probiotik yang efektif. Hal ini jika terlalu cepat probiotik diberikan sementara kosentrasi organik didasar msasih rendah, maka penggunaan probiotik tidak efeien. Jika probiotik terlambat diberikan maka penumpukan bahan organik didasar akan memicu berkembangnya organisme pathogen yang dapat membahayakan hewan budidaya (Nurbaya, 2010).

Pada perlakuan $\mathrm{C}$ dengan dosis probiotik 5\% menunjukkan peningkatan pertumbuhan yang maksimal untuk setiap parameter. Jumlah bakteri yang masuk ke dalam saluran pencernaan ikan dan hidup di dalamnya meningkat sejalan dengan 
dosis probiotik yang diberikan. Peningkatan daya cerna bermakna pula pada semakin tinggi nutrien yang tersedia untuk diserap tubuh sehingga pertumbuhan meningkat (Gandara, 2004).

\section{Kualitas Air}

Berdasarkan hasil pengukuran kualitas air (Tabel 3), didapatkan kisaran kualitas air pada masing-masing perlakuan selama penelitian masih dalam kisaran yang masih layak untuk kehidupan benih ikan patin.

Tabel 3. Kisaran kualitas air masing-masing perlakuan selama penelitian

\begin{tabular}{ccc}
\hline & \multicolumn{2}{c}{ Kualitas air } \\
\cline { 2 - 3 } Perlakuan & Suhu $\left({ }^{\circ} \mathrm{C}\right)$ & $\mathrm{pH}$ \\
\hline A & $26-28$ & $7,5-8$ \\
B & $26-28$ & $7,5-8$ \\
C & $26-28$ & $7,5-8$
\end{tabular}

Sumber. Data primer diolah (2012)

Berdasarkan Tabel 3 didapatkan suhu $26-28^{\circ} \mathrm{C}$ dan $\mathrm{pH} 7,5-8$, Arifin (1990) dalam Rahmawati (2010) menyatakan bahwa suhu air yang cocok untuk benih ikan patin (Catfish) berkisar antara $25-32{ }^{\circ} \mathrm{C}$ dan ikan patin mempunyai toleransi $\mathrm{pH}$ yang panjang yaitu 5,0-9,0 (Khairuman dan Sudenda, 2002 dalam Rahmawati, 2010).

\section{KESIMPULAN DAN SARAN}

\section{Kesimpulan}

Berdasarkan hasil penelitian dan pembahasan mengenai perbedaan dosis probiotik pada pakan terhadap tingkat kelangsungan hidup dan pertumbuhan benih ikan patin (Pengasius hypophthalmus) diperoleh kesimpulan bahwa perbedaan penambahan dosis probiotik dalam pakan tidak memberikan perbedaan yang nyata pada tingkat kelangsungan hidup benih ikan patin, tetapi memberikan perbedaan yang nyata pada pertumbuhan mutlak. Dari ketiga perlakuan perbedaan penambahan dosis probiotik yang diberikan diperoleh pertumbuhan mutlak untuk perlakuan $\mathrm{C}(5 \%)$ sebesar 8,40 \pm 0,70 gram, pada perlakuan B $(3 \%)$ sebesar $6,17 \pm 0,23$ gram dan diikuti pelakuan A (1\%) sebesar 5,80 \pm 1,51 gram. Hasil pengukuran kualitas air yang meliputi suhu dan $\mathrm{pH}$ selama penelitian menunjukkan angka yang masih layak untuk kehidupan benih patin dengan kisaran suhu $25-26^{\circ} \mathrm{C}$ dan $\mathrm{pH}$ 7,5-8.

\section{Saran}

Berdasarkan hasil kesimpulan di atas disarankan untuk mendapatkan dosis probiotik yang tepat perlu dilakukan penelitian selanjutnya mengenai pemberian dosis probiotik yang lebih beragam pada pakan buatan terhadap tingkat kelangsungan hidup dan pertumbuhan benih ikan patin (Pengasius hypophthalmus).

\section{DAFTAR PUSTAKA}

Atemalem. G. 2001. Analisis Kelayakan Investasi Usaha Pembenihan Ikan Patin Di Tapos Agro Lestari. Skripsi. Institut Pertanian Bogor. 
Atira. 2009. Pengaruh Berbagai Kosentrasi Inokulum Lactobacillus plantarum Trehadap Tingkat Kelangsungan Hidup Ikan Patin (Pangasius hypophthalmus). Universitas Tadulako

Aslamyah. S. 2011. Pengaruh Feed Additif Mikrob Bacillus sp dan Carnobacterium sp Pada Kadar Glukosa Darah Dan Laju Metabolisme Serta Neraca Energi Ikan Gurame (Osphronemus gouramy Lac.) Fase Omnivora. Riau

Effendie, M. I. 1979. Metode Biologi Perikanan. Yayasan Dewi Sri. Bogor.

Gandara. E. 2004. Pengaruh Penambahan Probiotik Bacillus sp Pada Pakan Komersil Terhadap Konversi Pakan dan pertumbuhan Ikan Patin. Jurnal Akuakultur Indonesia. Bogor.

Gaspers V., 1995. Tehnik Analisis Dalam Penelitian Percobaan. Tarsito. Bandung.

Kusriningrum, et al. 2008. Pengaruh Penambahan Probiotik Pada Paka Buatan Terhadap Pertumbuhan Dan Rasio Konversi Pakan Ikan Nila Gift (Oreochromis niloticus). Berkala Ilmiah Perikanan. Universitas Airlangga.

Laksmiwati, Ni Made. 2009. Pengaruh Pemberian Starbio Dan Effective Microorganisme- 4 ( EM-4) Sebagai Probiotik Terhadap Penampilan Itik Jantan Umur $0-8$ Minggu. Skripsi. Jurusan Produksi Ternak, Fakultas Peternakan, Universitas Udayana, Denpasar

Maesaroh, E. 2004. Berbagai Tingkat pemberian Pakan Pada Ikan Patin (Pangasius hypophthalmus) Dalam Karamba di Sungai Ciomas. Bogor. Skripsi. IPB. 19 hal.

Mahyuddin. K. 2010. Paduan Lengkap Agribisnis Patin . Penebar Swadaya, Anggota Ikapi. Jakarta. 6-3 hal.

Malik Tangko, A dan Abdul, M. 2008. Probiotik: Pemanfaatannya Untuk Pakan Ikan Berkualitas Rendah. Balai Riset Perikanan Budidaya Air Payau. Maros. 146 hal.

Nurbaya. 2010. Pengaruh Perbedaan Waktu Aplikasi Probiotik Terhadap Kualitas Dan Sintasan Pasca Larva Udang Windu (Penaeus monodon). Balai Riset Perikanan Budidaya Air Payau. Sulawesi Selatan

Puput, 2010. Program Kreatifitas Mahasiswa Efektifitas Penggunaan Probiotik Untuk Menghindari Investasi Argulus sp Pada Ikan Mas (Cyprinus carpio). Surabaya

Rahmawati, R., Septyan, A., dan Nurbakti, A. 2010. Pengaruh Pemberian Probiotik Dengan Dosis Yang Berbeda Terhadap Sintasan Dan Pertumbuhan Benih Patin Djambal (Pangasius djambal). Balai Riset Perikanan Budidaya Laut. Gondol.

Saputra, A., et al. 2010. Pertumbuhan Beberapa Strain Ikan Patin (Pengasius) Yang Dipelihara Dalam Tambak Bersalinitas Rendah. Pusat Riset Perikanan Budidaya. Jakarta.

Supriyanto. 2010. Pengaruh Pemberian Probiotik Dalam Pakan Terhadap Pertumbuhan Lele Sangkuriang. Skripsi. FMIPA Universitas Negeri Semarang. 